\title{
Vloga staršev pri socializaciji otrok in mladostnikov $v$ mladinskem domu
}

\author{
Bojan Macuh* \\ Fakulteta za komercialne in poslovne vede Celje, Lava 7, 3000 Celje, Slovenija \\ E-naslov: bojan.macuh@guest.arnes.si \\ Janez Domajnko \\ Mladinski dom Maribor, U1. Saše Deva 21, 2000 Maribor, Slovenija \\ jdomajnko@gmail.com
}

\section{Povzetek:}

Raziskovalno vprašanje: Kakšen je pomen vzgoje in socializacije ter vloge staršev v procesu bivanja mladostnikov in otrok v Mladinskem domu Maribor?

Namen: Ugotoviti želimo, ali je pri delu z mladostniki in otroki potrebno upoštevati razliko med vzgojo in socializacijo.

Metode: Raziskave smo izvajali v Mladinskem domu Maribor, kjer je bilo v času kvantitativne raziskave nameščenih 82 otrok in mladostnikov, na anketi vprašalnik pa jih je odgovarjalo 70 .

Rezultati: Sodelovanje s starši je pri otrocih in mladostnikih ocenjeno kot najmanj pomembno. Med drugim smo analizirali tudi kazalnike, kot so: strokovnost vzgojitelja/-ice, medsebojni odnosi, notranji delovni pogoji in razmere ter vrednote $\mathrm{v}$ odnosu do dela $\mathrm{z}$ otroki in mladostniki. Zanimal nas je pomen staršev pri vzgoji in socializaciji otrok v Mladinskem domu Maribor.

Organizacija: $Z$ raziskavo smo ugotavljali, kakšno vlogo imajo pri vzgoji in socializaciji starši otrok s čustvenimi primanjkljaji, ki so v institucionalni oskrbi.

Družba: Prispevek je pomemben z vidika življenja otrok in mladostnikov v Mladinskem domu Maribor, kakor tudi sobivanja otrok in mladostnikov ter njihovih staršev, kakor tudi vzgojiteljev, zaposlenih v instituciji.

Originalnost: Gre za eno prvih tako celovitih raziskav, ki je bila izvedena med otroci in mladostniki s čustvenimi primanjkljaji.

Omejitve raziskave/nadaljnje raziskave: Omejitev raziskave se kaže v tem, da so bili vključeni otroci in mladostniki, deloma tudi vzgojitelji. V prihodnje bo potrebno bolj konkretno vključiti še starše, ki so pomemben akter pri vzgoji in delu z njihovimi otroki v zavodu.

Ključne besede: otroci, mladostniki, starši, vzgoja, socializacija, dom.

\section{Uvod}

V Mladinskem domu Mariboru v procesu dela izvajamo vzgojo in socializacijo otrok in mladostnikov. 
Mladinski dom Maribor ima devet stanovanjskih skupin, ki so lokacijsko ločene, dve mladinski stanovanji, stanovanje, kjer se izvaja poldnevni program, terapevtsko kmetijo v Moščancih in v enoti Slivnica tri vzgojne skupine.

Delo poteka 24 ur na dan, celo leto, ob vikendih, počitnicah in praznikih. Delovna obveznost vzgojiteljev je 40 ur. Delo v tem okviru se izvaja kombinirano v skupini in izven nje. Po normativu ima stanovanjska skupina osem otrok in mladostnikov in štiri do pet vzgojiteljev. Vzgojitelji skupaj z otroki in mladostniki skrbijo za dinamiko in obveznosti, katere jim narekuje skupinsko življenje.

Otroci in mladostniki Mladinskega doma Maribor so vključeni in se izobražujejo v zunanjih osnovnih in srednjih šolah, $\mathrm{v}$ vseh programih nižjega in srednjega poklicnega izobraževanja, poklicno-tehniškega izobraževanja ter srednjega gimnazijskega izobraževanja. Veliko otrok in mladostnikov ima odločbo o usmeritvi z dodatno strokovno pomočjo, pedagoško pogodbo, možnostjo vključitve $\mathrm{v}$ projektno učenje. Vzgojitelji sodelujejo s šolskimi svetovalnimi službami, razredniki in posameznimi profesorji. Otroci in mladostniki so pogosto uspešni na šolskem področju.

Poudarek je na vzpostavitev dobrih odnosov s svojci in rejniki in rednim stikom z njimi, kar lahko pomembno in odločujoče vpliva na nadaljnji razvoj otroka in mladostnika. Svojci ali rejniki vedno sodelujejo pri izdelavi individualnih programov otrok in mladostnikov. Le tako organizirano se lahko kvalitetno usmerja otroka in ga pripravlja za bivanje ter vračanje $\mathrm{v}$ njegovo primarno okolje.

V empiričnem delu bomo predstavili vlogo staršev pri vzgoji in socializaciji otrok in mladostnikov v Mladinskem domu Maribor.

\section{Teoretična izhodišča}

Za vsakega otroka v procesu njegovega odraščanja sta pomembna elementa vzgoja in proces socializacije, skozi katerega otrok in kasneje mladostnik pridobiva potrebne vrednote za življenje.

Pomembna značilnost modernih družb je izjemno zanimanje za potek odraščanja otrok in mladostnikov. Dvajseto stoletje je od vseh obdobij najbolj vplivalo na proces poteka mladosti. Večina avtorjev omenja dvajseto stoletje, stoletje mladosti. Hall je kot prvi obdobje mladosti imenoval »adolescenca«. Za to obdobje je značilno viharništvo, upori mladih do avtoritete, stresi (Ule in Kuhar, 2003, str. 58).

Freeman (2011, str. 137) ugotavlja, da imajo otroci in mladostniki čustvene in duševne težave podobno kot odrasli, čeprav smo $\mathrm{v}$ preteklosti mislili, da otroci ne trpijo zaradi tesnobe, 
različnih strahov ali depresije. Sedaj vemo, da se navedene težave lahko pojavijo v vsaki starosti in so med seboj vraščanja $v$ družbo, zlasti razmerja med socialnim poljem in razvojem posameznika. Socialno polje ni sistem deklariranih pravil, temveč sistem realnih pravil in vrednot. Pri vzgojo gre za deklarirano zavestno dejavnost $\mathrm{v}$ duhu vrednot. $\mathrm{Z}$ vidika nadzorovanega procesa je vzgoja ožja od socializacije, saj je zavestna, sistematična, načrtna $v$ smeri doseganja namena in ciljev. Nenačrtovani nenamerni vplivi na posameznika, ki lahko potekajo na nivoju nezavednega, jih z zavestnim in organiziranim vplivom ne moremo odpraviti. Razlika je, da je pri vzgoji poudarek na oblikovanju človeka, pri socializaciji je poudarek na procesnem nastajanju, pri čemer so vključeni dejavniki nastajanja (Freeman, 2011, str. 137)

Iz Bele knjige (2011, v Krek in Meljak, 2011, str. 28) je razvidno, da je vzgoja ključni dejavnik in kompleksen pojem pri vzgojno-izobraževalnem sistemu, ki naj ne bi spodletel, saj je povezan s prenašanjem vrednot, norm, navad in prepričanj na mladostnike. Na drugi strani lahko poudarimo ustrezna vzgojna ravnanja in odnos vzgojiteljev do mladostnikov, ki so pogoj za uspešno prenašanje znanja. Vzgoja, vrednote in znanje so $\mathrm{v}$ praksi povezane in prepletene. Doseganje soglasja o temeljnih vrednotah predstavljajo človekove pravice in dolžnosti, ki jih zajema Ustava Republike Slovenije kot mednarodni dokument (prav tam).

Carsaro (1997; povz. po Rutar, 2013, str. 99) meni, da je mladostnik bil in je v razumevanju socializacije tisti, ki prevzema in ponotranja družbo. Mladostnika moramo razumeti kot nekaj, kar je ločeno od družbe, saj ga je potrebno šele oblikovati, da postane učinkovit član družbe.

Na Danskem otroke obravnavajo kot po naravi dobre. Želijo, da so spoštljivi in pričakujejo obojestransko spoštljivost. Njihovo načelo je, da moraš dajati, da bi prijel. Vladanje s strahom jim predstavlja problematičnost, ker ne spodbuja spoštovanja temveč strah. Pri strahu mladostniki vedno ne spoznajo, česa ne smejo, vpitju in tepežu se bodo izognili. Te navedbe ne prispevajo k zavedanju mladostnikov o lastnem osnovnem jazu. Življenje v sovražnem okolju, polnem vpitja in agresije, ne pomaga pri vzgoji (Alexander in Sandahl, 2017, str. 121).

Pri vzgoji je potrebno upoštevati razliko med vzgojo in socializacijo. Vzgojno delovanje krepi mladostnikove duhovne vrednote, da v procesu socializacije postanejo emancipirani, znajo moralno presojati, zavračati negativne družbene vplive in s svojo individualnostjo pozitivno vplivajo na razvoj družbe. V nadaljevanju bomo predstavili vlogo staršev / družine pri vzgoji otrok.

Družina je osnovna celica vsake družbe in otroci so nepogrešljiv delte skupnosti. Zavedati se je potrebno, da šele z rojstvom otroka starša tvorita to najpomembnejšo družbeno skupnost.

Družina je nenadomestljiva za človekovo socializacijo, njegovo čustvenost in vrednostni sistem. Ustrezna čustvenost je zelo pomembna, saj v nasprotnem primeru otrok zapade $\mathrm{v}$ 
deviantnost, ki se kaže v neprilagojenem in asocialnem vedenju. Delo s starši je zelo težko področje dela, saj lahko imajo starši veliko zaupanje v vzgojitelja, istočasno pa zelo velika pričakovanja. Mladostniki - otroci se vračajo v družino, zato obravnavanje otrok ne da bi hkrati obravnavali starše, le polovično. Obravnava družinske situacije nam lahko pojasni nekatere vedenjske vzorce, ki dajejo vzgojitelju osnovo za individualizirani vzgojni načrt, saj so starši vir informacij za lažjo diagnozo. Starši lahko delo vzgojiteljev podpirajo ali onemogočajo. Nerešeni odnosi mladostnikov z njihovimi starši pripeljejo do nadaljnjih frustracij, depresivnih stanj, nevrotičnih reakcij, begov in vedenjskih težav. Navedeni primeri so dovolj velik razlog za intenzivno delo s starši. Starši so edini dom otrok, čeprav je pogosto slab (Horvat, 2000, str. 23-24).

Starševstvo je v sodobni družbi postala zahtevna in odgovorna naloga. Rastoča odgovornost deluje danes kot breme, ovira pri vzgoji. Prav zaradi novih razsežnosti, novih razmerij in motivov, psiholoških želja, dilem, dvomov je starševstvo težak, za nekatere neuresničljivi projekt. Otroci so tu kot dejstvo in za vedno (Ule in Kuhar, 2003, str. 27).

Bouwkamp (2014, str. 119) meni, da je nedosleden starš tisti, ki nenehno menjuje pozicijo. V začetku je strog, ko otrok prične povzročati probleme in temu ni kos, popusti in nenadoma spremeni odnos, ponovno postane strog in kaznuje. Pri takšnem staršu otrok nikoli ne ve, pri čem je.

Devjak (2007, str. 127) ugotavlja, da je naloga strokovnega kadra v vzgojnih ustanovah je najti intenziven in dober kontakt s starši, ga negovati in sodelovati na nivoju partnerstva. Starše je potrebno vključevati v domski vsakdan. Ne smemo prezreti tistih staršev, ki se zaradi manj socialnih kompetenc radi umaknejo. Starši so pomemben dejavnik vključevanja otrok v domsko okolje, lahko popestrijo domski vsakdan in so pomemben vir za kvaliteto vzgoje in klime.

Naloga staršev v odnosu do otroka so oskrba, čustvena podpora, nadzor, skrb in vzgoja za družbeno odgovorno delovanje. Odnos se prične ob otrokovem rojstvu, ima več faz in se navadno konča s smrtjo staršev. Otroci so staršem pomemben del veselja in zadovoljstva, lahko pa tudi vir žalosti, skrbi, konfliktov, odvisno od medsebojnega ujemanja. Konflikti se pojavijo v borbi za ljubezen in medsebojno naklonjenost, zlasti v več številčni družini. Krize medsebojnih odnosov, se zlasti pojavljajo v obdobju otrokove adolescence, v večini primerov takrat starši ne morejo več slediti razvoju in spremembam otroka (Ule, 2009, str. 349).

Petrič (2011, str. 113) navaja, da starši svoje otroke vzgajajo v upanju in prepričanju, da vzgajajo najbolje. Kadar vzgoja ne poteka tako, kot so si zamislili, nastopi problem, pride do nezadovoljstva in konfliktov $v$ družini. $Z$ uvajanjem sprememb starši želijo rešiti problem nespoštljivosti, nesodelovanja, pojava agresivnosti pri svojih otrocih. Pozabljajo pa, da sta za vzpostavitev dobrega odnosa potrebna dva. Iz tega sledi, da lahko starši pričakujejo spremembe v odnosu z otroki, če so za spremembo pripravljeni tudi oni. 
Ugotavljamo, da je starševstvo odgovorna naloga, ki je prepletena z različnimi dejavniki, ki vplivajo na razvoj in vzgojo otroka / mladostnika v sodobnem času.

V nadaljevanju bomo ugotavljali, ali mladostniki ocenjujejo dimenzijo sodelovanje s starši kot najmanj pomemben element $\mathrm{v}$ okviru bivanja v Mladinskem domu Maribor.

\section{Metodologija}

Izvedli smo kvantitativno raziskavo, $\mathrm{v}$ kateri smo anketirali otroke in mladostnike $\mathrm{v}$ Mladinskem domu Maribor.

V Mladinskem domu Maribor je bilo v času raziskave nameščenih 82 mladostnikov, na anketi vprašalnik pa jih je odgovarjalo 70. Od tega je bilo 45 mladostnikov ali $64 \%$ in 25 mladostnic ali $36 \%$ od celotne populacije (Slika 1 ).

口Število mladostnikov

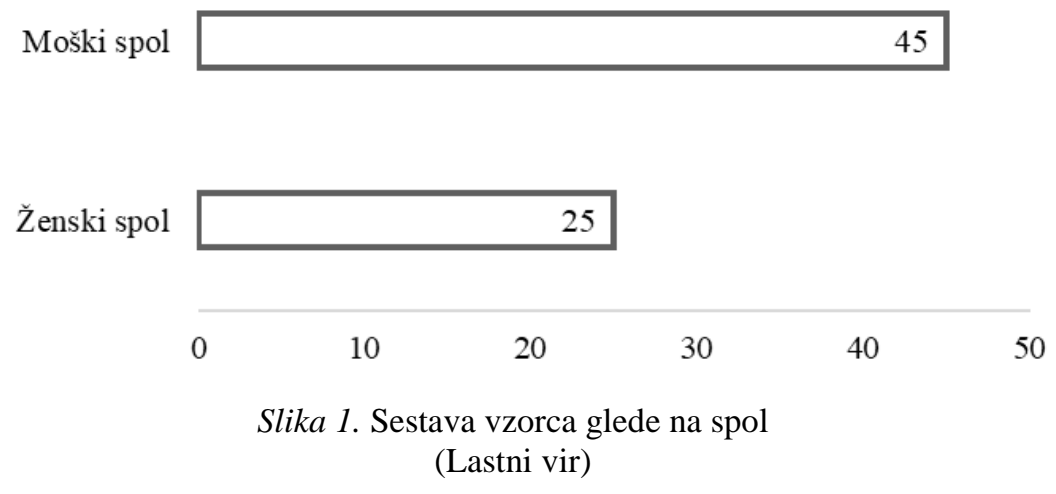

57 mladostnikov je bilo starih od 14-18 let, kar je predstavljalo 81,4\%. 7 mladostnikov je bilo staro 19 in več let, kar je predstavljalo $10 \% .6$ mladostnikov je bilo starih od 11 do 13 let, kar je predstavljalo $8,6 \%$ od celotne populacije (Slika 2). 


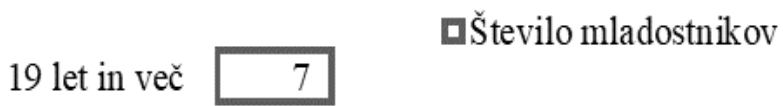

od 14 do 18 let

od 11 do 13 let

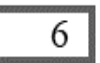

$\begin{array}{lllllll}0 & 10 & 20 & 30 & 40 & 50 & 60\end{array}$

Slika 2. Sestava vzorca glede na starost

(Lastni vir)

\section{Sodelovanje s starši}

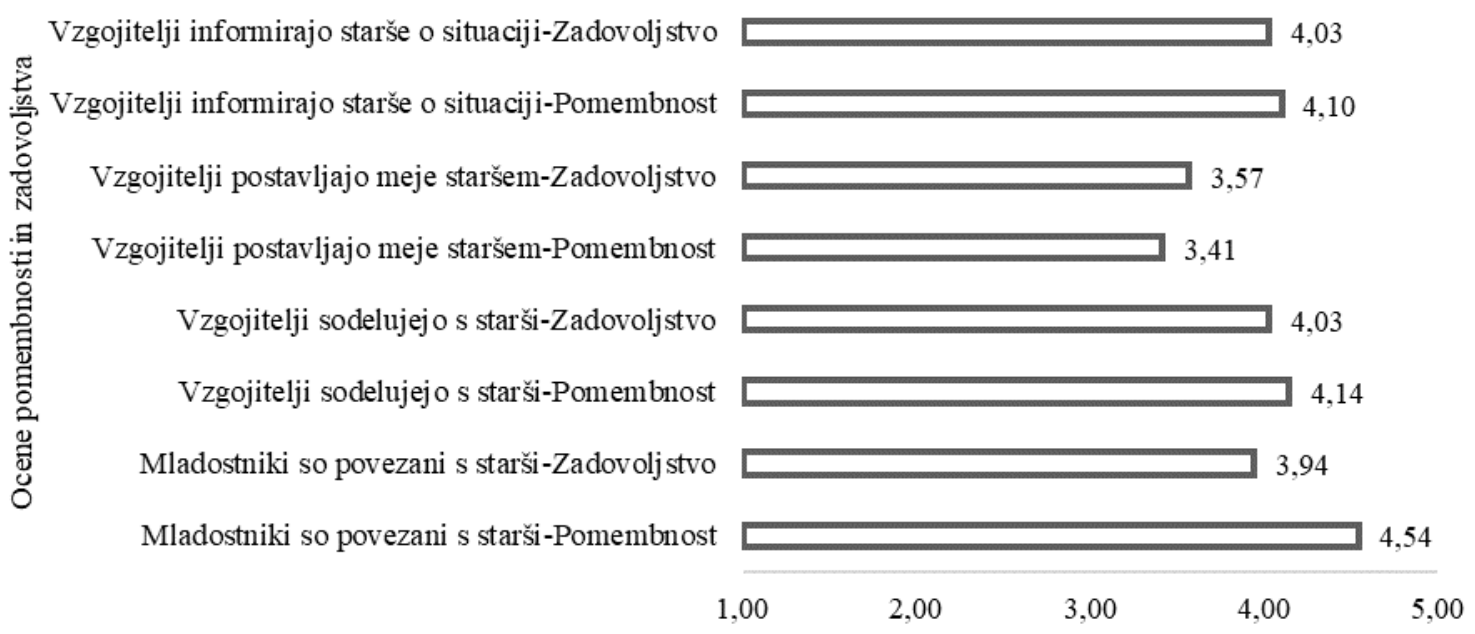

Slika 3. Ocena zadovoljstva in pomembnosti vidikov sodelovanja vzgojiteljev s starši in povezavo mladostnikov s starši (Lastni vir)

Pri kazalniku sodelovanje s starši je razvidno, da so mladostniki najbolj zadovoljni s trditvijo, da »vzgojitelji informirajo starše o situaciji«, s povprečno oceno 4,03. Najmanj so zadovoljni s trditvijo, da »vzgojitelji postavljajo meje staršem«, s povprečno oceno 3,75. Ta trditev je zanje tudi najmanj pomembna in jo povprečno ocenjujejo $\mathrm{z}$ oceno 3,41. Največjo pomembnost predpisujejo trditvi, da so »mladostniki povezani s starši« z oceno 4,54 (Slika 3). Povprečne ocene zadovoljstva in pomembnosti so večje od 3,5. Iz tega sledi, da so mladostniki v povprečju zadovoljni in jim je sodelovanje s starši pomembno. 


\section{Rezultati in razprava}

Postavili smo hipotezo H1, pri kateri smo preverjali, ali mladostniki ocenjujejo dimenzijo sodelovanje s starši kot najmanj pomemben element $\mathrm{v}$ okviru bivanja $\mathrm{v}$ Mladinskem domu Maribor.

Hipoteza H1 se potrdi, če mladostniki dimenzijo »sodelovanja s starši« ocenijo kot najmanj pomembno med vsemi dimenzijami v vprašalniku na lestvici 1 do 5 . Predvidevali smo, da je ocena mladostnikov glede sodelovanja z njihovimi starši najmanj pomembna.

Pri H1 smo torej preverjali, ali mladostniki ocenjujejo dimenzijo sodelovanje s starši kot najmanj pomemben element. Preverili sem vseh šest kazalnikov (dimenzij) iz anketnega vprašalnika glede na ocenitev pomembnosti s strani mladostnikov. Med temi je bila tudi ocenitev pomembnosti sodelovanja s starši, kar prikazujemo v tabeli 1.

Tabela 1. Pomembnost sodelovanja s starši (Lastni vir)

\begin{tabular}{|c|c|c|c|c|c|}
\hline & & $\begin{array}{l}\text { Mladostniki so } \\
\text { povezani s starši } \\
\text { - pomembnost. }\end{array}$ & $\begin{array}{c}\text { Vzgojitelji } \\
\text { sodelujejo s starši } \\
\text { - pomembnost. }\end{array}$ & $\begin{array}{c}\text { Vzgojitelji } \\
\text { postavljajo meje } \\
\text { staršem - } \\
\text { pomembnost. } \\
\end{array}$ & $\begin{array}{c}\text { Vzgojitelji } \\
\text { informirajo starše } \\
\text { o situaciji - } \\
\text { pomembnost. }\end{array}$ \\
\hline \multirow[t]{2}{*}{ Število } & Veljavno & 70 & 70 & 70 & 70 \\
\hline & Manjka & 0 & 0 & 0 & 0 \\
\hline \multicolumn{2}{|l|}{ Srednja } & 4,5429 & 4,1429 & 3,4143 & 4,1000 \\
\hline \multicolumn{2}{|l|}{ Mediana } & 5,0000 & 5,0000 & 4,0000 & 5,0000 \\
\hline \multicolumn{2}{|l|}{ Način } & 5,00 & 5,00 & 5,00 & 5,00 \\
\hline \multicolumn{2}{|c|}{ Minimalna } & 2,00 & 1,00 & 1,00 & 1,00 \\
\hline \multicolumn{2}{|c|}{ Maksimalna } & 5,00 & 5,00 & 5,00 & 5,00 \\
\hline
\end{tabular}

Skupno povprečje vseh trditev pomembnosti v kazalniku »sodelovanje s starši« je 4,05 (Tabela 1).

»Sodelovanje s starši« - mladostniki so najbolj zadovoljni s trditvijo, da »vzgojitelji informirajo starše o situaciji«. Najpomembnejša jim je trditev, da so »mladostniki povezani s starši«. Najmanj so zadovoljni s trditvijo, da »vzgojitelji postavljajo meje staršem《. Ta trditev je zanje tudi najmanj pomembna. $\mathrm{V}$ povprečju so vse trditve zadovoljstva in pomembnosti $\mathrm{V}$ kazalniku ocenili z več kot 4 . To nakazuje, da so mladostniki v povprečju z vsemi trditvami zadovoljni in so jim le-te pomembne.

Ugotavljali smo še naslednje kazalnike, kot so lik vzgojitelja, strokovnost vzgojitelja/-ice, medsebojni odnosi, notranji delovni pogoji in razmere ter vrednote. $\mathrm{V}$ nadaljevanju predstavljamo, kako so mladostniki ocenili naslednje kazalnike: 
»Lik vzgojitelja« - mladostniki so najbolj zadovoljni s trditvijo, da ima »vzgojitelj občutek za delo z mladostniki« in tudi najbolj pomembna je ta. Najmanj so zadovoljni s trditvijo, da »vzgojitelj začuti vsakega mladostnika«, najmanj pa jim je pomembna trditev, da je »vzgojitelj dosleden, strog, a korekten«. V povprečju so vse trditve zadovoljstva in pomembnosti v kazalniku ocenili z več kot 4 . To nakazuje, da so mladostniki v povprečju z vsemi trditvami zadovoljni in so jim vse trditve pomembne.

»Strokovnost vzgojitelja« - mladostniki so najbolj zadovoljni s trditvijo, da »vzgojitelj skrbi za mladostnike«. Najpomembnejša zanje je trditev, da »vzgojitelj pomaga mladostnikom v kritičnih situacijah«. Najmanj so zadovoljni s trditvijo, da je »vzgojitelj pripravljen uvajati novosti« in da je »vzgojitelj avtoritativen«. Najmanj jim je pomembna trditev, da je »vzgojitelj avtoritativen«. V povprečju so vse trditve zadovoljstva in pomembnosti V kazalniku ocenili z več kot 4 . To nakazuje, da so mladostniki v povprečju zadovoljni z vsemi trditvami in so jim vse le-te pomembne.

»Medsebojni odnosi« - mladostniki so najbolj zadovoljni s trditvijo, da se »s sovrstniki dobro razumejo«. Najpomembnejša je zanje trditev, da se »v MD dobro počutijo«. Najmanj so zadovoljni s trditvijo, da »obstaja toleranca vzgojiteljev nad mladostniki«. Ta trditev je mladostnikom najmanj pomembna. $\mathrm{V}$ povprečju so vse trditve zadovoljstva in pomembnosti $\mathrm{v}$ kazalniku ocenili z več kot 4 . To nakazuje, da so mladostniki v povprečju z vsemi trditvami zadovoljni in so jim le-te tudi pomembne.

»Notranje delovne razmere« - mladostniki najbolj zadovoljni s trditvijo, da imajo »mladostniki zagotovljene prevoze v šolo«. Najpomembnejša jim je trditev, da »MD zagotavlja mladostnikom varnost«, najmanj pa so zadovoljni s trditvijo, da so »prostori za interesno dejavnost urejeni«. Najmanjšo pomembnost predpisujejo trditvi, da so »prostori za interesno dejavnost urejeni«. V povprečju so vse trditve zadovoljstva in pomembnosti $\mathrm{V}$ kazalniku ocenili z več kot 4 . To nakazuje, da so mladostniki v povprečju z vsemi trditvami zadovoljni in so jim te trditve tudi pomembne.

$»$ Vrednote« - mladostniki so največje zadovoljstvo podali pri trditvi, da »se vzgojitelji zavzemajo za mladostnike«. Največjo pomembnost predpisujejo trditvi, da »lahko izražajo svoje mnenje, najmanj pa so zadovoljni s trditvijo, da »lahko izražajo svoje mnenje«. Najmanjšo pomembnost so pripisali trditvi, da »so do njih načelni«. V povprečju so vse trditve zadovoljstva in pomembnosti $\mathrm{v}$ kazalniku ocenili $\mathrm{z}$ več kot 4 . To nakazuje, da so mladostniki v povprečju z vsemi trditvami zadovoljni in so zanje te trditve pomembne.

Glede na pomembno vlogo staršev pri vzgoji in socializaciji otrok smo bili presenečeni nad dejstvom, da so kazalniku sodelovanje s starši izmed vseh trditev namenili najmanj pomembno vlogo. Na osnovi ugotovitev, da mladostniki ocenjujejo le-ta kazalnik kot najmanj pomembnega, smo potrdili hipotezo H1, v kateri smo naključno rezultat tudi predvidevali. 
Zaskrbljujoče je dejstvo, da so otroci in mladostniki elementu sodelovanje s starši dali tako slabo oceno.

\section{Zaključek}

Ugotavljali smo, da so vzgoja in socializacija ter vloga staršev $\mathrm{v}$ procesu bivanja mladostnikov in otrok v Mladinskem domu Maribor zelo pomembni, čeprav v nadaljevanju nismo dobili potrditev, da bi bila vloga staršev tako pomembna, kot smo glede na praktično sodelovanje z njimi pričakovali.

Ob kazalniku »Sodelovanje s starši« smo ugotavljali smo še naslednje kazalnike, kot so lik vzgojitelja, strokovnost vzgojitelja/-ice, medsebojni odnosi, notranji delovni pogoji in razmere ter vrednote. Vse smo tudi predstavili. Ko smo ugotavljali kazalnike, kot so strokovnost vzgojitelja/-ice, medsebojni odnosi, notranji delovni pogoji in razmere ter vrednote $\mathrm{v}$ odnosu do dela $\mathrm{z}$ otroki in mladostniki, smo glede na pomembno vlogo staršev pri vzgoji in socializaciji otrok bili presenečeni nad dejstvom, da so kazalniku sodelovanje s starši izmed vseh trditev namenili najmanj pomembno vlogo. Zaskrbljujoče je, da so otroci in mladostniki elementu sodelovanje s starši dali tako slabo oceno in jim veliko več pomenijo npr. vrednote, medosebni odnos, bivalni pogoji in predvsem vzgojitelji in vzgojiteljice. To samo potrjuje dejstvo, kako pomemben je lik vzgojitelja/-ice, ki so z njimi praktično 24 ur na dan. Menimo, da je vloga staršev navkljub rezultatom, ki smo jih predstavili, zelo pomembna, saj so vezni člen za delo z otroki in mladostniki.

Kot prispevek k stroki menimo, da je pri vzgoji potrebno upoštevati razliko med vzgojo in socializacijo. Vzgojno delovanje krepi mladostnikove duhovne vrednote, da $\mathrm{v}$ procesu socializacije postanejo emancipirani, znajo moralno presojati, zavračati negativne družbene vplive in s svojo individualnostjo pozitivno vplivajo na razvoj družbe.

$\mathrm{Z}$ raziskavo smo ugotavljali, da imajo starši mnogo manjšo vlogo pri vzgoji in socializaciji otrok s čustvenimi primanjkljaji, ki so v institucionalni oskrbi, kot smo predvidevali. Glede na praktične ugotovitve pri neposrednem delu s starši in otroci ter mladostniki smo menili, da je to sodelovanje neizogibno in nujno potrebno pri vključevanju otrok in mladostnikov $\mathrm{v}$ vzgojno izobraževalni proces (osnovna in poklicna/srednja šola), kakor tudi za nadaljnje življenje.

Na osnovi ugotovitve bomo v prihodnje pripravili raziskavo o pomembnosti lika vzgojitelja/ice pri delu z otroki in mladostniki v Mladinskem domu Maribor. Vzgojitelj / vzgojiteljica sta tista akterja, ki ob strokovni službi, neposrednem sodelovanju z vzgojno izobraževalnimi institucijami in Centri za socialno delo največ pripomorejo pri socializaciji otrok in mladostnikov. 


\section{Reference}

1. Alexander Joelle, J. in Sandahl Dissing, I. (2017). Vzgoja po Dansko: Kaj eni najsrečnejših ljudi na svetu vedo o vzgoji samozavestnih in sposobnih otrok. Ljubljana: Mladinska knjiga.

2. Bouwkamp, R. in Bouwkamp S. (2014). Blizu doma: priročnik za delo z družinami. Ljubljana: Znanstvena založba Filozofske fakultete.

3. Devjak, T. (2007). Pravila in vzgojno delovanje šole. Ljubljana: Pedagoška fakulteta.

4. Horvat, M. (2000). Delo z vedenjsko in osebnostno motenim otrokom in mladostnikom. Ljubljana: Zavod Republike Slovenije za šolstvo.

5. Krek, J. in M. Metlak. (2009). Bela knjiga o vzgoji in izobraževanju. Ljubljana: Zavod za šolstvo Republike Slovenije.

6. Freeman, D. in Freeman, J. (2011). Spoznajte svoj um: vsakdanje čustvene in duševne težave ter kako jih premagati. Ljubljana: Gnostica.

7. Peček, M. (2009). Moč vzgoje: sodobna vprašanja o teoriji vzgoje. Ljubljana: Tehniška založba Slovenije.

8. Petrič, M. (2011). Staršsevstvo je lep, a odgovoren poklic. Nova Gorica: Melior, Založba Educa.

9. Rutar, S. (2013). Poti do participacije otrok v vzgoji. Koper: Univerza na Primorskem.

10. Ule, M. (2009). Psihologija komuniciranja in medsebojnih odnosov. Ljubljana: Fakulteta za družbene vede.

11. Ule, M. in Kuhar, M. (2003). Mladi, družina, staršsevstvo. Ljubljana: Fakulteta za družbene vede, Center za socialno psihologijo.

\section{$* * *$}

Doc. dr. Bojan Macuh je prof. soc. in slov. Doktorski študij je zaključil na Pedagoški fakulteti Univerze na Primorskem, pred tem pa magistrski študij sociologije na Filozofski fakulteti Univerze v Mariboru. Od leta 2009 je predavatelj na Fakulteti za poslovne in komercialne vede v Celju, kjer predava sociologijo. Na Gea College v Ljubljani občasno predava od leta 2013 poslovno etiko in organizacijsko kulturo. Na Višji šoli za kozmetiko in velnes predava predmet čustvena inteligenca in osebnostni razvoj. Je avtor in soavtor znanstvenih in strokovnih monografij, priročnikov ter več znanstvenih, strokovnih in poljudnih člankov. S svojimi prispevki kot avtor in soavtor je sodeloval na več mednarodnih znanstvenih konferencah. Hkrati je avtor tudi več leposlovnih del za odrasle, mladino in otroke.

Janez Domajnko je mag. poslovnih ved. Magistrski študij je zaključil na Fakulteti za komercialne in poslovne vede v Celju. Pred tem je zaključil visoko šolski študij na Fakulteti za organizacijske vede Univerze v Maribor in končal višje šolski študij na Strojni fakulteti Univerze v Mariboru. Od leta 1997 je vzgojitelj v Mladinskem domu Maribor - enota Slivnica. Pridobil je andragoško-pedagoško izobrazbo na Pedagoški fakulteti Univerze v Mariboru in dokvalifikacija za delo z otroki, ki imajo motnje vedenja MVO na Pedagoški fakulteti Univerze v Ljubljani.

\section{Abstract: \\ The Role of Parents in Socialization of Children and Adolescents in the Juvenile Home}

Research question: What is the importance of education and socialization of adolescents and children and parental roles in Maribor juvenile centre during their living there? 
Purpose: We want to establish whether it is necessary to consider the difference between education and socialization when working with adolescents and children.

Methods: The research was carried out at the Maribor juvenile centre where 82 children and adolescents resided at the time of the quantitative survey, and 70 of them answered the questionnaire.

Results: Children and adolescent consider cooperation with parents the least important. Among other things, we analysed indicators such as: educator's professionalism, interpersonal relationships, internal working conditions, and values in relation to work with children and adolescents. We were interested in the importance of parents in education and socialization of children in Maribor juvenile centre.

Organization: The study identified the role of parents of children with emotional deficits in institutional care in the education and socialization of children.

Society: The contribution is important from the perspective of the lives of children and adolescents in Maribor juvenile centre and the coexistence of children and adolescents and their parents, as well as the educators employed by the institution.

Originality: This is the first such comprehensive study conducted among children and adolescents with emotional deficits.

Research limitations/further research: A limitation of the research is that children and adolescents, and partly educators, were included. In further research, it will be necessary to involve more parents who are an important actor in education and work with their children in the institution.

Keywords: children, adolescents, parents, education, socialization, home.

Copyright (c) 2020 Bojan MACUH, Janez DOMAJNKO

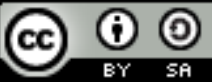

Creative Commons License

This work is licensed under a Creative Commons Attribution-ShareAlike 4.0 International License. 